\title{
A IDENTIDADE TERRITORIAL NO PATRIMÔNIO ARQUITETÔNICO EM CANOINHAS/SC
}

Cinthia Wambier Adimari ${ }^{1}$ Alexandre AssisTomporoski²

Resumo: O presente artigo identifica os fatores geográficos, econômicos, históricos e sociais que foram responsáveis pela formação da identidade do município de Canoinhas e sua importância para a constituição de seu patrimônio arquitetônico. Para tanto, foram utilizados como referenciais teóricos os conceitos de território, identidade e patrimônio arquitetônico. Embasado em processos resultantes de combinações naturais, econômicas e sociais, que são compostos por elementos endógenos e exógenos, gerou-se uma estrutura técnico-produtiva apoiada em forças de produção e relações sociais ligadas ao extrativismo da erva mate e da madeira. Essa estrutura proporcionou o espraiamento, na paisagem urbana no município de Canoinhas, do patrimônio arquitetônico de edificações em madeira.

Palavras-chave: identidade territorial. Patrimônio arquitetônico. Arquitetura de madeira. Região do Contestado. Canoinhas.

\section{THE TERRITORIAL IDENTITY IN ARCHITECTURAL HERITAGE IN CANOINHAS/SC}

Abstract: The present article identifies the geographic, economic and social combinations that were responsible for the formation of the identity of the municipality of Canoinhas and its importance for the formation of the architectural patrimony. For this, the concepts of territory, identity and architectural patrimony are worked as a fundamental theoretical reference. Based on ancient structures and processes, in natural, economic and social combinations, which are composed of endogenous and exogenous elements, a technical-productive structure was generated, based on production forces and social relations linked to the extractivism of mate grass and wood. This structure, among others, was directly responsible for the spreading, in the urban landscape in the municipality of Canoinhas, of the architectural heritage of wooden buildings.

Keywords: Territorial identity. Architectural heritage. Wood architecture. Contestant Region. Canoinhas.

\section{IDENTIDAD TERRITORIAL EN EL PATRIMONIO ARQUITECTÓNICO DE CANOINAS/SC}

Resumen: El presente artículo identifica las combinaciones geográficas, económicas y sociales que fueron responsables de la formación de la identidad del municipio de Canoinhas y su importancia para la formación del patrimônio arquitectónico. Para ello, se trabaja, com o referencial fundamental teórico, los conceptos de territorio, identidad y patrimonio arquitectónico. En las estructuras y processos antiguos, em combinaciones naturales, económicas y sociales, que están compuestas por elementos endógenos y exógenos, se generó una estrutura técnico-

\footnotetext{
1 Instituto Federal de Santa Catarina, Canoinhas, Brasil, cinthiaadimari2@gmail.com, https://orcid.org/0000-0002-1769-4681.

2 Universidade do Contestado, Departamento de desenvolvimento Regional, Canoinhas, Brasil, alexandre@unc.br, https://orcid.org/0000-0002-3042-7844.
} 
productiva apoyada em fuerzas de producción y relaciones sociales ligadas al extractivismo de la hierba mate y de la madera. Esta estructura, entre otras, fue responsable directa por el espáfico, en el paisaje urbano en el municipio de Canoinhas, del patrimonio arquitectónico de edificaciones en madera.

Palabras clave: Identidad territorial. Patrimonio arquitectónico. Arquitectura de madera. Región del Contestado. Canoinhas.

\section{Introdução}

O município de Canoinhas, localizado no estado de Santa Catarina (Figura 01), possui uma área territorial de 1.140,394 Km2 e integra a região do Planalto Norte Catarinense $^{3}$, com uma população, segundo o censo realizado em 2010 , de 54.319 habitantes (IBGE, 2018).

A região foi habitada pelos indígenas dos grupos Xoklengs e Kaingangs. Em 1728, com a abertura Estrada das Tropas ${ }^{4}$, ampliou-se a ocupação e o povoamento, bem como os conflitos interétnicos com tropeiros e, mais tarde, com os imigrantes assentados na região.

A partir do século XIX, a economia da região constituiu-se baseada no extrativismo, principalmente na exploração da erva-mate e, mais tarde, da madeira. Os proprietários dos grandes latifúndios exploravam essas riquezas e detinham 0 poder político local. Com a Lei das Terras ${ }^{5}$, em 1850, os fazendeiros proprietários proibiram 0 acesso dos caboclos $^{6}$ aos ervais nativos de suas propriedades, restringindo a coleta da erva-mate, produto importante para a subsistência da população pobre da região, fato que resultou na elevação da tensão social.

A exploração capitalista das terras - incrementada sobremaneira com o aporte de capital estrangeiro - e as inúmeras injustiças praticadas contra a população local, influenciaram a deflagração da Guerra do Contestado (1912-1916), um dos maiores movimentos sociais da história brasileira. Apesar de milhares de pessoas terem

\footnotetext{
${ }^{3}$ O Planalto Norte Catarinense possui uma área territorial de $11.041,365 \mathrm{~km}^{2}$, representando $11,58 \%$ da área territorial do estado de Santa Catarina, e é constituído por 13 (treze) municípios, a seguir enumerados, em ordem alfabética: Bela Vista do Toldo, Campo Alegre, Canoinhas, Ireneópolis, Itaiópolis, Mafra, Major Vieira, Monte Castelo, Papanduva, Porto União, Rio Negrinho, São Bento do Sul, Três Barras (IBGE, 2018).

${ }^{4}$ Estrada de Tropas: caminho que interligava os Estados do Rio Grande do Sul e São Paulo, transportando produtos e animais para comercialização, até o início do século XIX

${ }^{5}$ No Brasil, a Lei de Terras (lei no 601 de 18 de setembro de 1850), representou um marco na questão fundiária, e estabelecia a compra como a única forma de acesso à terra.

${ }^{6} \mathrm{O}$ termo caboclo, empregado pelos habitantes do planalto, ou seja, o habitante pobre do meio rural. Embora não haja uma conotação étnica nesta palavra, frequentemente o caboclo era mestiço, muitas vezes negro. Mas, a característica principal desta palavra é que distingue uma condição social e cultural, ou seja, são caboclos os homens e mulheres pobres, pequenos lavradores e posseiros, agregados ou peões que vivem em economia de subsistência e são devotos de São João Maria. Desta forma, havia também brancos caboclos, alemães e polacos acaboclados (MACHADO, 2004; TOMPOROSKI, 2013).
} 
sucumbido em consequência do conflito bélico, instaurou-se um processo de esquecimento e silenciamento do movimento do Contestado, levado a efeito pelas classes dominantes - com a conivência do Estado catarinense - que conduziu à fragilização dos laços de pertencimento, afetou a memória social, e originou na população em geral um desconhecimento de sua própria história e de sua região.

Esse processo estendeu-se pelas décadas subsequentes até a atualidade, impactando sobre a memória da região e seu patrimônio cultural. Houve um esquecimento da história das populações indígenas, da Guerra do Contestado e da luta dos caboclos. Adicionalmente, a preservação da memória de outros eventos históricos também foi relegada a segundo plano, como a chegada dos imigrantes ou o domínio econômico, político e fundiário das empresas estrangeiras do setor madeireiro e ferroviário, que atuaram na região durante décadas.

Em contraste, o patrimônio arquitetônico necessita de identificação e difusão das informações sobre sua origem, técnicas de construção, história de ocupação, etc, senão a maioria dos cidadãos tenderá a desconhecer a importância daquela edificação para a cidade, para a região e para sua própria história. A valorização do patrimônio arquitetônico de um determinado município representa uma ferramenta importante para a construção de um sentimento de pertencimento, o qual, por sua vez, possui relação com o fortalecimento de uma identidade territorial e com os processos de desenvolvimento.

Sob esse enfoque, o objetivo central do artigo consistiu em verificar as combinações geográficas, econômicas e sociais responsáveis pela formação da identidade do município de Canoinhas e sua relação com o patrimônio arquitetônico ${ }^{7}$.

Para a consecução desse objetivo, foram utilizados aportes teóricos segregados em dois grupos: um que considera a identidade cultural de um povo, de uma população, sua formação, seu desenvolvimento e a noção de espaço geográfico e território, pois toda atividade humana se desenvolve em praticamente

\footnotetext{
7 O presente artigo foi elaborado em três fases, mediante procedimentos de coleta de dados bibliográficos e análise documental. A primeira fase da pesquisa caracterizou-se pelo levantamento e seleção de informações em fontes bibliográficas: livros, periódicos, dissertações, teses, artigos de jornais e revistas Em seguida, com o intuito de identificar os elementos históricos, culturais e econômicos pertinentes ao tema geral, e, também, prover a seleção prévia dos bens, realizou-se a análise de fontes documentais oriundas de acervos idôneos, públicos e particulares. Os dados também foram coletados em bases disponíveis na rede mundial de computadores, em especial: Ministério da Cultura; IPHAN; UNESCO; Secretarias de cultura estadual e municipal; Conselho de Arquitetura; universidades. Na terceira fase, procedeu-se à organização e redação do texto, que contou com figuras ilustrativas e mapas temáticos, confeccionados em softwares como ArcGIS. As fotos das edificações foram efetuadas pelos autores em janeiro de 2019
} 
qualquer lugar do nosso planeta e possui uma dimensão espacial (CUNHA, 2015). Nesse grupo, foram empregados os autores: Cholley (1964); Santos (1977 e 1985). Alicerçado nessa base teórica conceitual, o segundo grupo teórico concerne ao processo de ocupação e desenvolvimento da região do Vale do Contestado e do município de Canoinhas e a formação do patrimônio arquitetônico. Entre os autores, citam-se: Tomporoski e Marchesan (2016); Bartmann (2009); Tomporoski, (2012; 2015; 2016; 2018); Machado (2001; 2004); Milani (2014); Goulart Filho (2009).

Acerca de sua estrutura, o artigo divide-se em três partes: na primeira parte, são debatidas as abordagens sobre patrimônio arquitetônico e identidade territorial; na segunda, descreve-se o processo de ocupação e formação da identidade de Canoinhas; na terceira, são apresentados dados técnicos e estéticos sobre as características históricas da arquitetura em madeira da região, assaz marcante na paisagem urbana, assim como a técnica construtiva.

\section{Patrimônio arquitetônico e identidade territorial}

A cultura é um fenômeno resultante das atividades promovidas pelo ser humano. Deste modo, considera-se a arquitetura uma produção social e cultural decorrente do desejo da coletividade, que contribui para a formação da identidade de um território, de grupos e categorias sociais e para o resgate da memória, desencadeando uma ligação entre o cidadão e suas raízes (OLIVEIRA, DINIZ E WALDNER, 2017).

Um monumento é uma edificação ou sítio histórico de caráter exemplar, por seu significado na trajetória de vida de uma comunidade e por suas características peculiares de forma, estilo e função (HORTA, GUNBERG e MONTEIRO, 1999). O patrimônio arquitetônico relaciona-se intimamente com 0 uso, característica intrínseca dele, pois mantém uma relação complexa com suas finalidades estética e simbólica. Ademais, possui a capacidade de estimular a memória das pessoas historicamente vinculadas, se tornando alvo de estratégias que visam a sua promoção e preservação (OLIVEIRA, DINIZ E WALDNER, 2017).

Para Camilo (2017), o patrimônio arquitetônico possui os elementos utilizados no planejamento e ordenação da dinâmica de crescimento das cidades, representando um dos itens estratégicos no reconhecimento da identidade de grupos sociais. Sendo assim, trata-se de um fator de desenvolvimento para a sociedade, necessitando de uma gestão adequada, a fim de permitir que os espaços 
culturais sejam usados para beneficiar uma comunidade receptora. Para o autor, a arquitetura é patrimônio relacionado a um bem paterno valioso, que justifica sua herança e preservação, por nela estar incutida a memória e a identidade de quem o deixa e de quem o herda.

Da Silva (2000), destaca que o Patrimônio arquitetônico não deve ser entendido apenas como os vestígios concretos da história, pois todas as manifestações materiais de cultura criada pelo homem têm sua existência física num espaço e num determinado período. Ademais, também existe uma escolha cultural subjacente, que consiste na vontade de levar a herança do patrimônio cultural a gerações futuras, além de um sentimento de posse por parte de determinados grupos sociais ao legado que é herdado na coletividade

Assim, Rocha (2012) afirma que a preservação do patrimônio cultural corresponde a um aspecto fundamental para o desenvolvimento cultural de um povo, pois repercute em sua formação sociocultural. O patrimônio arquitetônico é o conjunto de bens materiais que contam a história de um povo e sua relação com o meio onde estão inseridos, sendo o legado herdado do passado e transmitido às novas gerações.

De acordo com Pelegrini (2007), as políticas de preservação adotadas no Brasil atribuíram aos bens arquitetônicos valores de mercado, colaborando com o consumo cultural e a transformação da paisagem historicamente construída em "ruínas patrimoniais" de marketing citadino. Isso acarreta a exclusão da população residente e a adaptação desses espaços a novos usos, um fenômeno conhecido como gentrificação ${ }^{8}$, o que ocasionou ao espaço arquitetônico a superficialidade das restaurações. O autor ainda destaca que esse fato diminui do patrimônio edificado ao cenário da indústria cultural e sua lógica do entretenimento, dissociando toda a fruição dos bens culturais da memória social e histórica.

Conforme Luchiari (2005), o patrimônio arquitetônico tem atribuído às paisagens urbanas contemporâneas um novo sentido no campo do consumo cultural. Tornou-se um recurso revestido de valores mercadológicos, descompromissados com o passado e com o lugar, devido à uma tendência global que reflete a mundialização das relações, dos valores e das manifestações culturais. Essa apropriação vem seguindo a conduta de transformação do patrimônio em

\footnotetext{
${ }^{8}$ O termo gentrificação foi atribuído por Glass, (1964), que utilizou a expressão para descrever um processo iniciado em 1950 no centro de Londres, quando algumas áreas residenciais deterioradas, tradicionalmente ocupadas por operários, estavam sendo transformadas em áreas residenciais para grupos de status socioeconômico mais elevado.
} 
mercadoria, assim como a sua refuncionalização está impregnada da ideologia do consumo, em detrimento das práticas culturais representativas do sentimento de pertencimento das culturas e populações locais.

As imposições do mercado globalizado, das ideologias de consumo e da indústria cultural, vêm banalizando as formas do patrimônio arquitetônico, desqualificando o sentido de memória. Assim, as formas encontram-se cada vez mais misturadas com os traços de diferentes culturas, revelando as identidades culturais do nosso tempo, onde o consumo estético das formas tem mais valor do que o seu uso social democrático (LUCHIARI, 2005).

Coaduna-se com essa perspectiva a proposição de Oliveira, Diniz e Waldner (2017), que ressaltam a necessidade de preservar o patrimônio arquitetônico no Brasil por meio de um movimento de valorização da cultura Nacional, que propicie a proteção desses bens, destacando o seu simbolismo materializado. Salientam, ainda, que as políticas de preservação do patrimônio podem ser promovidas através de uma série de medidas constituídas por normas, suporte técnico e canais de participação da sociedade. Com isso, a valorização de políticas preventivas, compensatórias e de estímulo, bem como, a diversidade de alternativas de proteção, podem ser construídas de forma sistêmica e abrangente, adicionando ações voltadas à conscientização preservacionista.

Para Zanirato e Ribeiro (2006), a conservação do patrimônio cultural exige políticas de valorização, mediante investimentos públicos, que não favoreçam a exploração mercadológica dos bens patrimoniais, e sim, o seu usufruto pela população contribuinte. A garantia dos usos sociais do patrimônio requer gestão adequada dos bens, bem como a defesa e aplicação de políticas públicas adotadas por ações compartilhadas com a sociedade. Deste modo, os investimentos públicos com a educação patrimonial fortalecem o conhecimento da sociedade civil, permitindo que tratem de assuntos pertinentes ao patrimônio com igualdade.

Funari (2006), aponta para a necessidade de conciliar situações de ensino e aprendizagem com a preservação do patrimônio cultural, daí a importância da educação patrimonial.

Há várias maneiras de analisar o espaço. Santos (1985), propõe que estrutura, processo, função e forma, entrelaçados dialeticamente, sejam as categorias de análise do espaço geográfico e, consequentemente, do território. Essas categorias são interdependentes entre si, de tal modo que as análises 
isoladas poderão comprometer o concreto pensado, e a realidade poderá ser representada superficialmente.

Assim, o processo considera um conjunto de ações, dadas historicamente, que movimentam, ainda que de maneira contraditória, toda uma estrutura baseada em elementos econômicos, sociais, políticos, naturais e jurídico-institucionais, moldando-os de acordo com o tempo e o espaço. Ainda de acordo com Santos (1985), a forma é o aspecto visível e pode ser definida como as criações humanas, materiais ou não, que representam o lugar onde os objetos e as ações se realizam. Por sua vez, função é a atividade desempenhada pelo objeto criado, podendo mudar com o tempo, e se refere às atividades da sociedade, que permitem a existência e reprodução social. As formas e as funções assumem as características de cada grupo social. É uma concepção histórica e relacional da geografia e do espaço. ${ }^{9}$

A identidade territorial é o elemento que diferencia determinado agrupamento populacional, sua identidade está diretamente ligada ao meio natural (físico e biológico), à cultura, às relações sociais e econômicas. É uma resultante de processos históricos e relacionais que envolvam os elementos. Deste modo, a identidade territorial gera e orienta os processos de territorialização, que reforçam o processo de intensificação entre comunidade e território, tornam-se referência para orientar o processo de desenvolvimento territorial. (DALLABRIDA, 2017).

Segundo Nigro (2001), os conceitos de patrimônio e território possuem correspondências, pois: (i) ambos detêm uma dupla natureza material e ideal, constituindo-se como referências geradoras de controle ideológico e político; (ii) ambos exercem uma função mnemônica, além de inscreverem o tecido social dentro da continuidade histórica. Uma das características comuns mais importantes é que ambos só podem existir a partir de uma apropriação coletiva que thes atribui significações e que se expressa no território.

\footnotetext{
${ }^{9}$ Santos (1977) afirma que: "se abandonarmos o ponto de vista da sociedade em geral e abordarmos a questão sob o ângulo de determinações específicas que a tornam concreta, essas determinações específicas se tornariam uma mera potência, uma simples vocação". Segundo Espíndola; Cunha (2015, p. 233), esse método de abordagem "trata-se das totalidades históricas e que devem ser consideradas como expressão socioespacial dos processos que se singularizam em função de determinadas combinações. Essas ampliam as possibilidades das análises, pois a realidade é fruto da relação dialética entre os aspectos naturais e humanos. Essas relações são estabelecidas em múltiplas escalas (mundial, nacional, regional e local), e permitem compreender um determinado objeto de estudo num universo mais amplo". E isso, se aproxima das combinações geográficas que "podem ser divididas em três grandes categorias: as que resultam, unicamente, da convergência de fatores físicos; aquelas, já mais complexas, que são, a um tempo, de ordem física e de ordem biológica; as mais complicadas e, por isso mesmo, mais interessantes, que resultam da interferência conjunta dos elementos físicos, dos elementos biológicos e dos elementos humanos" (CHOLLEY, 1964, p. 140).
} 
Destarte, a identidade de uma sociedade perpassa pelos elementos culturais mais importantes, percebidos além das expressões folclóricas, artesanais e organizacionais dos sujeitos. Tais elementos devem expressar o reconhecimento de vida dos sujeitos e o significado delas para com estes sujeitos (MILANI, 2014).

$\mathrm{Na}$ literatura neomarshalliana, identificou-se os laços entre os atores sociais como uma das razões para a formação dos sistemas produtivos locais. Portanto, o desenvolvimento corresponde a um processo de mudança continuada, situando história e territorialidade, integrado em dinâmicas globais, sustentado na potencialidade de recursos e ativos materiais e imateriais, genéricos e específicos existentes no território (DALLABRIDA, 2017).

Nesse contexto, os territórios oferecem recursos específicos que diversificam os espaços e estabilizam as localizações das atividades econômicas. Os agentes e as políticas locais desempenham papel importante na constituição e gestão dos produtos específicos existentes no território. As perspectivas econômicas estão relacionadas com a capacidade dos grupos em gerar processos de ocorrência dos recursos (BENKO E PECQUEUR, 2001).

Depreende-se, portanto, que o patrimônio cultural é um símbolo material ou imaterial importante para a formação da identidade de um território. No que segue, serão analisados alguns dos elementos presentes no processo histórico que configurou o município de Canoinhas, e que são responsáveis pela sua formação socioeconômica, proporcionado, deste modo, as condições necessárias para a identificação dos patrimônios que representam aquele território no tempo e no espaço.

\section{O território e a formação da identidade de canoinhas}

O processo de ocupação e formação histórica influencia o desenvolvimento de regiões, territórios ou países. Cabe destacar que a região na qual se insere o município de Canoinhas ${ }^{10}$ integra o território do Contestado (Figura 01), palco do

\footnotetext{
10 O município de Canoinhas está situado na microrregião geográfica que é estabelecida com as especificidades relacionadas à organização do espaço: a estrutura da produção primária (uso da terra, orientação da agricultura, grau de diversificação da produção, nível tecnológico, entre outros); a estrutura da produção industrial (valor da transformação industrial e pessoal ocupado); e a interação espacial (área de influência dos centros sub-regionais e centros de zona). Deste modo, a Microrregião de Canoinhas, estabelecida pelo IBGE, é composta pelos municípios de Mafra, Major Vieira, Monte Castelo, Papanduva, Porto União, Santa Terezinha, Timbó Grande e Três Barras (Bartmann, 2009).
} 
movimento sertanejo do Contestado (1912-1916). Esse território se estende pelas regiões norte e centro-oeste do Estado de Santa Catarina.

Figura 01 - Mapa de localização do município de Canoinhas - SC

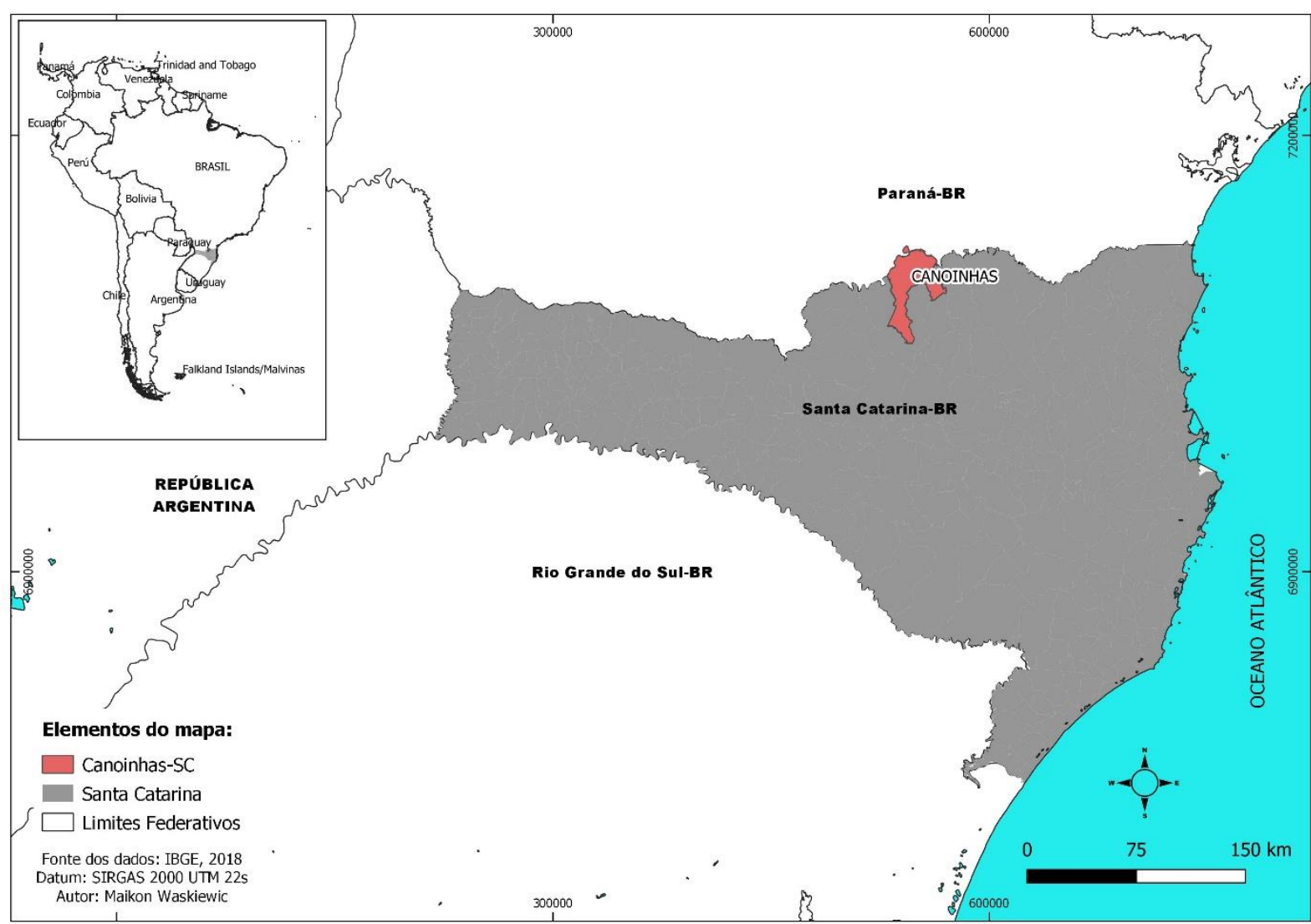

Fonte: Waskiewick, (2019)

Identifica-se uma ampla rede hidrográfica distribuída por todo território, que é singrado pelos rios Negro e Iguaçu. O Rio Negro tem extensão de 363 quilômetros e recebe pela margem esquerda a contribuição de 22 afluentes, dentre os quais os Rios Canoinhas, Preto, São João e Negrinho. O Rio Iguaçu, com extensão de 158 quilômetros, demarca o limite entre os Estados do Paraná e Santa Catarina, com 12 afluentes, destacando-se os Rios Jangada, Timbó Paciência e Espingarda. Essa área apresenta solos úmidos, com elevada concentração de matéria orgânica ${ }^{11}$, e seu relevo se destaca pela existência de colinas baixas em superfície regular. $\mathrm{Na}$ formação vegetal predominam: a Mata da Araucária; a erva-mate; a imbuia; as canelas; a bracatinga; os camboatás; e os sassafrás (TOMPOROSKI e MARCHESAN, 2016). Iguaçu. (TOMPOROSKI E MARCHESAN, 2016). 
Tendo em vista as combinações físicas e biológicas, Tomporoki (2018), destaca que o território do Contestado ${ }^{12}$, onde se insere o município de Canoinhas, em seus primórdios, foi ocupado predominantemente por populações indígenas do grupo Xokleng, que não praticavam a agricultura, apenas a caça e a coleta como meio de sobrevivência e desfrutavam na floresta de araucária de seu melhor habitat. A região foi ocupada a partir de 1600, além das populações indígenas, também por caboclos, um grupo miscigenado, fruto da interação entre indígenas, negros e portugueses ligados a pequenas atividades pecuárias e agrícolas (MARCHESAN, 2013).

Tomporoski; Marchesan (2016) afirmam que a partir do ano de 1728, ocorreu a abertura da Estrada de Tropas, caminho que interligava os estados do Rio Grande do Sul e São Paulo, propiciando o início do processo de povoamento da região. Essa estrada permaneceu ativa por quase duzentos anos, pela qual eram transportados produtos e animais para serem comercializados principalmente na feira de Sorocaba, em São Paulo. Convém destacar que os tropeiros necessitavam realizar paradas para descanso e alimentação. Esses locais transformaram-se ao longo do tempo em vilas e cidades.

Em decorrência do Caminho de Tropas e da ampliação do comércio de erva mate, durante as primeiras décadas do século XIX, as primeiras levas de imigrantes foram assentadas na região. No ano de 1829, ocorreu a instalação de uma colônia de imigrantes em Rio Negro, Paraná. Subsequentemente, sucessivas levas de imigrantes se inseriram na região. Conforme Bartmann (2009), em 1829, um expressivo contingente de germânicos chegou à região de Canoinhas, proveniente, principalmente, de São Bento do Sul, Joinville, Corupá, Jaraguá do Sul e Blumenau, fugindo da epidemia de febre amarela que assolava aqueles municípios. A partir dos anos 1890, acentuou-se a chegada de imigrantes europeus, destacando-se a nacionalidade alemã, polonesa e ucraniana (TOMPOROSKI, 2018).

Esses imigrantes exploravam diversas áreas florestais, sobretudo, no interior do Rio Grande do Sul (o Planalto Médio, o Alto Uruguai) e de Santa Catarina (como o vale do Rio do Peixe e o planalto de Canoinhas), além de colônias existentes em áreas de vegetação mista e em áreas florestais paranaenses, localizadas no Primeiro (região de Curitiba) e Segundo Planaltos (região de Ponta Grossa). A

\footnotetext{
12 A Guerra do Contestado ocorreu entre 1912 e 1916, gestada por fatores sociais, políticos, religiosos, econômicos e culturais, teve como epicentro a região sob análise. O município de Canoinhas foi envolvido no conflito, principalmente nos anos de 1914 e 1915, período marcado pela grande expansão rebelde do movimento sertanejo (TOMPOROSKI, 2012).
} 
exploração da madeira teve início por volta de 1820 e intensificou-se no período de 1860-1880. Os imigrantes derrubavam a mata da fachada atlântica e a utilizavam para diversos fins, como construção civil, naval, meios de locomoção, e exportação das toras através dos portos de São Francisco e Itajaí (IBGE, 1968).

A chegada dos imigrantes e o acréscimo das atividades econômicas favoreceu a formação de bairros rurais, ${ }^{13}$ onde um conjunto de famílias mantinham conexões entre si, sendo que a proximidade das residências não era um fator limitador. Esse fato resumia o sentimento de pertencimento e união de pessoas em prol da coletividade, no qual se fortaleciam costumes que asseguravam relações solidárias entre os habitantes. Destacavam-se práticas de trabalho relacionadas com a roça cabocla, a criação comunal de animais e o pixirum ${ }^{14}$ (TOMPOROSKI, 2016).

As práticas religiosas também representavam elemento que definia a configuração dos bairros rurais. Percebe-se esse fato com a devoção pelos monges João Maria ${ }^{15}$ e José Maria, que representavam práticas coletivas, enraizadas com o modo de vida dos habitantes da Microrregião de Canoinhas. Pode-se afirmar que as práticas religiosas fomentavam a sociabilidade e a união daquela população (TOMPOROSKI, 2015) ${ }^{16}$.

É oportuno salientar que um aspecto de ordem jurídica contribuiu decisivamente para a conformação da microrregião de Canoinhas: a aprovação da Lei de Terras, de 1850. A lei versava sobre as aquisições de terras devolutas por outro título que não fosse o de compra. Excetuaram-se as terras situadas nos limites do Império com países estrangeiros em uma zona de 10 léguas, as quais poderiam ser concedidas gratuitamente (BRASIL, 1850). A aprovação dessa nova legislação

${ }^{13} \mathrm{O}$ conceito de bairro rural é minuciosamente analisado na obra MELLO E SOUZA, Antônio Cândido. Os Parceiros do Rio Bonito: estudos sobre o caipira paulista e a transformação dos seus meios de vida. São Paulo: Duas Cidades, 2001.

${ }^{14}$ Mobilização comunitária entre os lavradores, na época da colheita, envolvendo auxílio mútuo.

${ }^{15}$ Fraga (2006), assinala que na Região Sul existiu um peregrino, com cabelos e barbas longas, que desejava a solidão e o isolamento: São João Maria, visto como justo e severo consigo mesmo, repartindo com o próximo a sua fé. Sabe-se que ele era solteiro, eremita, de estrutura baixa e cor clara, fixando cruzes por onde passava para estimular o símbolo da fé cristã. Registra-se o seu desaparecimento no início do século XX. Foi exaltado como mensageiro do bem e venerado santo pelos caboclos. Em 1912, apareceu Miguel Lucena e Boa Ventura (José Maria), se dizendo irmão de João Maria, um curandeiro, que conquistou seus primeiros seguidores em Campos Novos (SC).

16 Outra característica que Machado (2001) destaca em relação à formação do território é a presença do coronelismo. O coronelismo consistiu em uma prática político-social, do meio rural e das pequenas cidades do interior, que floresceu durante a Primeira República (1889-1930), configurando uma forma de mandonismo a partir da qual a elite, encarnada emblematicamente pelo proprietário rural, controla os meios de produção, detendo o poder econômico, social e político local. Tal fenômeno era encabeçado por indivíduos que costumavam ser fazendeiros e proprietários de grandes latifúndios e que exerciam o poder político local. Eles contavam com aliados, pessoas que residiam no entorno da propriedade, representados pelos peões. Esse fato permitia que o coronel exercesse funções de polícia, exacerbando ainda mais o domínio desse grupo sobre as terras. 
teve como consequência o impedimento do acesso à terra pelos não-brancos: exescravos, indígenas e caboclos, em detrimento da instalação de imigrantes europeus por meio da ação das companhias colonizadoras. A Lei de Terras, de 1850, legalizou o latifúndio e fomentou a constituição de uma estrutura agrária direcionada para a agroexportação, possibilitando a concentração fundiária, que resulta extremamente excludente.

As riquezas naturais do território oportunizaram a geração de dois tipos de produto de base extrativista: a madeira serrada e a erva mate. Deste modo, a região atraiu indústrias, contribuindo para a fixação dos imigrantes em grupos próximos às instalações fabris (MILANI, 2014).

Agregando-se aos fatores mencionados, um elemento histórico importantíssimo emergiu na região: a construção de uma ferrovia interligando os estados do Sul com o Sudeste do Brasil. Com esse objetivo, o governo brasileiro assinou com a Brazil Railway Company um contrato para construção da ferrovia com pontos de partida e de chegada nas cidades de Itararé em São Paulo e de Santa Maria, no Rio Grande do Sul (TOMPOROSKI, 2016).

A construção dessa ferrovia atraiu grande número de imigrantes para a região, os quais se assentaram, primeiramente, nos municípios de Rio Negro (PR) e União da Vitória (PR), com interesse preliminar no comércio ao longo da ferrovia.

O contrato para construção da ferrovia estabelecia a concessão de terras adjacentes ao leito dos trilhos à empresa contratada. Com o objetivo de explorar as riquezas naturais, a Brazil Railway Company constituiu uma subsidiária, a madeireira Southern Brazil Lumber and Colonization Company, (TOMPOROSKI, 2013) construída em Três barras ${ }^{17}$, o que fomentou a instalação de imigrantes na região de Canoinhas (BARTMANN, 2009).

A empresa Lumber Company estruturou um processo industrial mecanizado e de grande organização técnica para a extração da madeira. Inicialmente, o corte das toras na floresta era feito por trabalhadores que adentravam a mata. Posteriormente, eram ligadas a cabos de aço, erguidas por guinchos movidos a vapor comprimido e arrastadas até o leito dos ramais. No entanto, quando as madeiras eram arrastadas destruíam toda a vegetação de menor porte, incluindo a erva mate, elemento fundamental de sobrevivência para a população local. Após removidas até o leito da ferrovia, eram levadas até a serraria situada na vila de Três Barras, para serem

17 Três Barras foi município paranaense até o ano de 1917, quando pelo Acordo de Limites entre Paraná e Santa Catarina, passou a integrar o estado catarinense na condição de distrito de Canoinhas. 
beneficiadas, armazenadas e transportadas para comercialização pela linha férrea até os portos de São Francisco do Sul e Paranaguá (TOMPOROSKI, 2012).

Por outro lado, essas terras eram ocupadas pelos caboclos, que exploravam racionalmente aquele território, criando relações sociais com seus pares. Porém, esse modo de vida foi impactado pela 'racionalidade' do capital, de tal modo que a empresa estrangeira desestabilizou a organização econômica e sociocultural da população local.

Além disso, a companhia norte-americana objetivava fixar descendentes europeus na região sob enfoque. A empresa iniciou a colonização com imigrantes poloneses, ucranianos e, mais tarde, no vale do rio do Peixe, chegaram, principalmente, italianos e alemães (VALLENTINI E RADIN, 2011). Portanto, com o advento da Lumber Company na região de Três Barras, vastas áreas desmatadas foram loteadas e vendidas pela empresa a colonos do leste europeu, estabelecidos ali por ação do estado do Paraná com o intuito de povoar o território e obter controle efetivo sobre a região em disputa - contestada - com Santa Catarina. Esse processo aumentou exponencialmente o fluxo de imigrantes em toda aquela região. Dois grandes movimentos marcaram a imigração polonesa para o Paraná, o primeiro no período entre 1890 e 1896, quando entraram no estado cerca de vinte e oito mil imigrantes, e o segundo no período entre 1907 e 1914, com a chegada de outros vinte e sete mil poloneses.

A análise desse processo histórico permite compreender por que a microrregião de Canoinhas é marcada por uma estrutura econômica e social baseada em uma intensa diversidade cultural, que, ao longo do tempo, permitiu a mescla de diferentes etnias, moldando a construção da identidade do território. Sendo assim, a população da região não possui um aspecto cultural preponderante, mas diversos elementos que interagem, os quais perpassam distintos modos de viver. Na mesma direção, as características fisiográficas (relevo, vegetação, pedologia, clima) ajudaram a proporcionar atividades econômicas associadas, sobretudo, à exploração da madeira e ao extrativismo da erva-mate.

No território do Contestado, a erva mate e a araucária despertaram o interesse dos colonizadores e, principalmente, do capital estrangeiro. $\mathrm{Na}$ microrregião de Canoinhas predominava a presença da cobertura vegetal da Floresta de Ombrófila Mista (mata de araucária) e nos sub-bosques desta floresta destaca-se a presença da erva-mate. A intensa exploração da erva mate integrava a economia regional até 1930. Com a instalação da serraria norte americana, os ervais 
nativos foram desaparecendo, ou tiveram sua população drasticamente reduzida, milhares de árvores milenares, responsáveis pelo sustento da fauna e dos caboclos (MARCHESAN, 2013).

A Lumber Company foi estatizada no ano de 1940, e com a nova política econômica implementada pelo presidente Getúlio Vargas (1930-1945), tornou-se cada vez mais comum a formação de grandes empreendimentos industriais madeireiros na região, surgindo grupos empresariais poderosos com várias serrarias espalhadas por todo território (FERREIRA, 2009).

Em suma, esse arcabouço produtivo e econômico caracterizou o desenvolvimento urbano no município de Canoinhas. Portanto, esse processo influenciou a paisagem urbana, fato evidenciado pela grande quantidade de edificações residenciais em madeira até hoje existentes no município.

Apesar da descrição relatada pelo jornal canoinhense ${ }^{18}$ é preciso salientar que o processo de desenvolvimento, principalmente no modo capitalista, gera elementos de revés, principalmente porque é pautado na exploração do homem pelo homem, resultando em: (i) concentração de renda e de terra; (ii) graves problemas de ordem ambiental; (iii) desequilíbrios institucionais. Ademais, segundo Tomporoski (2016, p. 86), essas relações físico-naturais, sociais, econômicas e culturais são importantes para a formação da identidade de um Território. Conforme assinala Santos (1985), a identidade territorial é um elemento diferenciador de um determinado agrupamento populacional, proveniente de processos históricos e relacionais que envolvem o conhecimento de um povo, as edificações, os monumentos, os museus, os dialetos, as crenças, os arquivos históricos, as relações sociais das famílias, as empresas, as organizações políticas, formando deste modo o patrimônio identitário que pode ser decomposto em programas para o desenvolvimento regional.

\section{A arquitetura residencial em madeira e a sua importância para formação da identidade urbana da região de canoinhas (sc)}

O espaço urbano conta a sua história através da arquitetura. Fabricada na perenidade de seus bens materiais, a forma arquitetônica tem a capacidade de legar ao tempo os vestígios de sua existência. Assim, a cidade, além de ser um continente

\footnotetext{
18 "Canoinhas é uma das mais bem traçadas cidades do Planalto Catarinense. Vale a pena sair da Capital do Estado para conhecer o seu progresso e fruir os seus irresistíveis e múltiplos encantos. Delineada com esmero e capricho sob uma alta inspiração de bom gosto de quem a traçou, tudo nela é majestoso e singular. [...]. Lá possui todos os requisitos d'uma grande cidade que tem vida própria, que podemos e devemos mostrar, com justa ufania, aos turistas que procuram o nosso país, ansiosos de aspetos deslumbrantes e de novos lugares, onde a civilização e o progresso mais se afirmem requintadamente" (Jornal Correio do Norte, 31 dez 1955).
} 
das experiências humanas, também é um registro, uma escrita, uma materialização de sua própria história (ROLNIK, 2009). A história da cidade é o estudo da própria trajetória no espaço e no tempo, que permite identificá-la e compreendê-la.

$\mathrm{Na}$ região Sul do Brasil, a utilização de habitações em madeira está incorporada à paisagem urbana, principalmente no Rio Grande do Sul e em Santa Catarina. No estado catarinense, principalmente no Vale do Itajaí, Planalto Serrano, Meio-Oeste e Oeste, essas edificações surgiram a partir de meados do século XIX e início do século $X X$, no período de colonização do estado pelos imigrantes europeus: alemães, italianos, eslavos, entre outros. A adesão da madeira ao espaço urbano ocorreu devido a disponibilidade da matéria-prima de qualidade, que proporcionou ciclos econômicos resultantes da extração e beneficiamento, os quais, na atualidade, ainda geram reflexos na economia do estado, desde o reflorestamento, extração, beneficiamento e industrialização da madeira (BOGO, 2017).

Segundo Grad (2008), as primeiras edificações em madeira surgidas no território catarinense foram cabanas indígenas, com caráter efêmero devido as características nômades daquela população. Eram compostas por varas e revestidas de palha, capim e couro. Elas eram móveis ou fixas e às vezes instadas em crateras como os abrigos conhecidos como "buracos de bugres". Os europeus que vieram a se instalar se espelharam nos modelos indígenas para criar seus primeiros abrigos.

No fim do século XIX e início do século $X X$, ocorreu o desenvolvimento de novas tecnologias, em diferentes áreas, acarretando, por exemplo, o surgimento de serrarias movidas à água, e com elas o desenvolvimento de edificações com estruturas mais robustas. As casas apresentavam aberturas mais amplas, varandas incorporadas, elementos decorativos seriados, pintura e mata juntas (Figura02). 
Figura 02 - Primeira moradia do pastor da igreja Luterana, construída em 1920

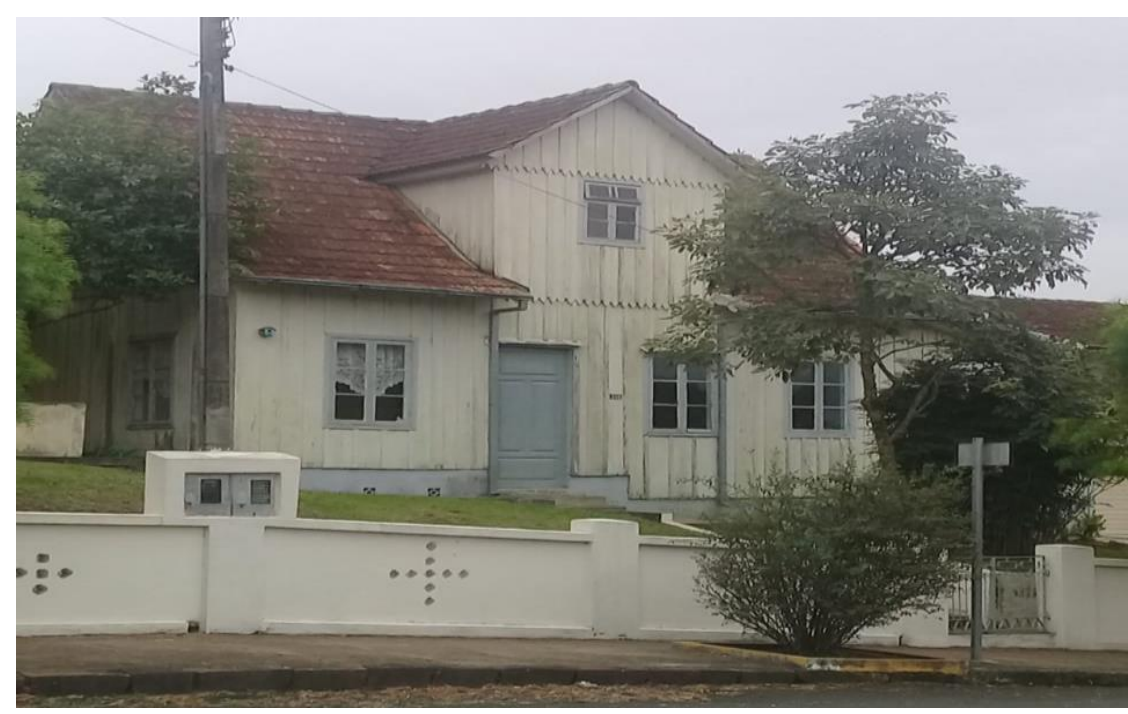

Fonte: Adimari (2019)

No início do século XX, surgiram edificações ligadas ao ecletismo arquitetônico, com fachada principal em alvenaria de tijolos e corpo em madeira. Essas fachadas se caracterizavam por janelas contornadas por ressaltos, parapeitos salientes, platibandas decoradas com inscrições, balaustradas e ânforas, utilizando internamente a mesma técnica de madeira com mata-juntas (Figura 03). Naquela época, a madeira passou a ser mais bem aproveitada com a padronização das dimensões e cortes, obtendo-se regularidade nos componentes, aumentando-se a produção e reduzindo o custo e o desperdício. ${ }^{19}$

\footnotetext{
${ }^{19}$ Naquela época foi instalada a empresa Southen Brazil Lumber Colonization Company - conforme visto anteriormente - a qual, além de explorar a madeira, também exportava madeiramento serrado para casas de uso corrente nos Estados Unidos, o que representava a vanguarda da tecnologia industrial para aplicação em construções no país. A madeireira Lumber começou a processar a madeira do tronco aos componentes de construção mais diversificados, exportando praticamente o madeiramento pronto para montagem de casas, entre outros: vigas; barrotes; tabuas de fechamento; divisória; forros; assoalhos; madeiramento para cobertura. Entretanto, parte desse material era consumido no mercado interno de Santa Catarina e na região de Canoinhas, sendo utilizado, sobretudo, na construção de prédios comerciais e residenciais (foto 3) e com mais intensidade na primeira metade do século XIX (CLARO, 1991).
} 
Figura 03: Hotel Sholze, construído em 1927

Fonte: Adimari (2019)

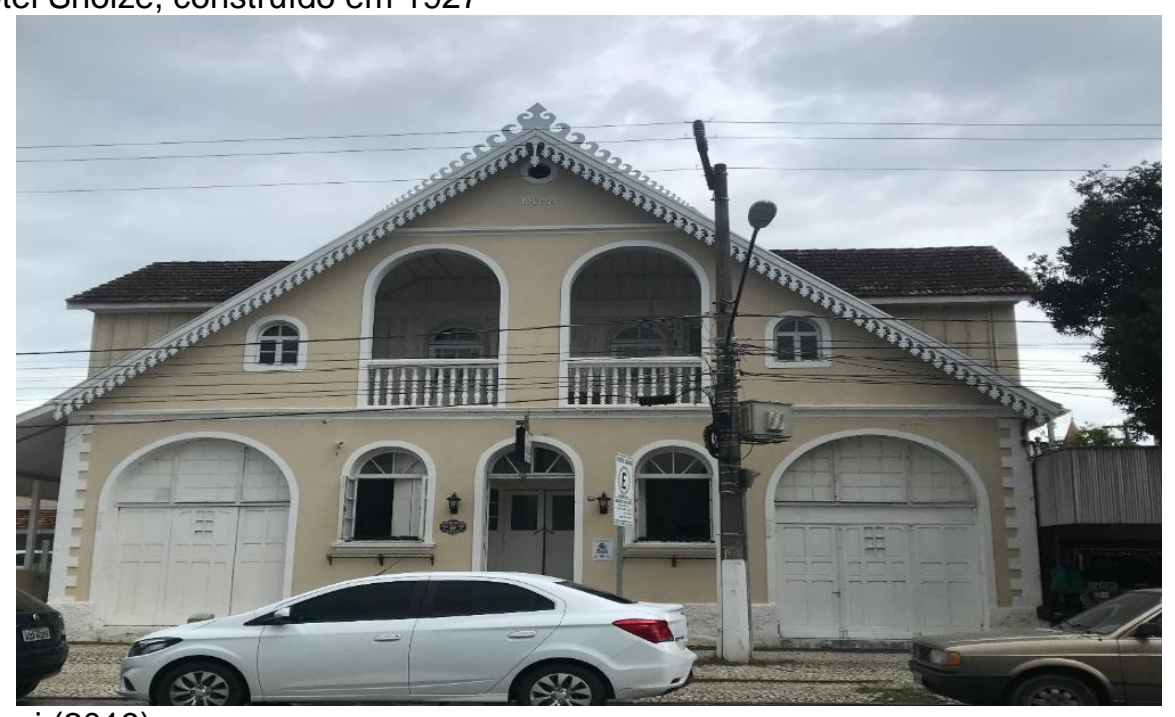

Essas construções apresentam padrão diversificado das casas que eram construídas em períodos anteriores, com sistema construtivo simplificado, composto por montante vertical, sobre as quais as tábuas eram pregadas horizontalmente e encaixadas através do sistema macho/fêmea, tendo como resultado paredes mais lisas. Essas obras ${ }^{20}$ se espraiavam na paisagem urbana de Canoinhas, Três Barras, Rio Negrinho e Porto União (IPHAN, 2011) (Figura 04).

Figura 04 - Residência na região central de canoinhas, construída em 1920

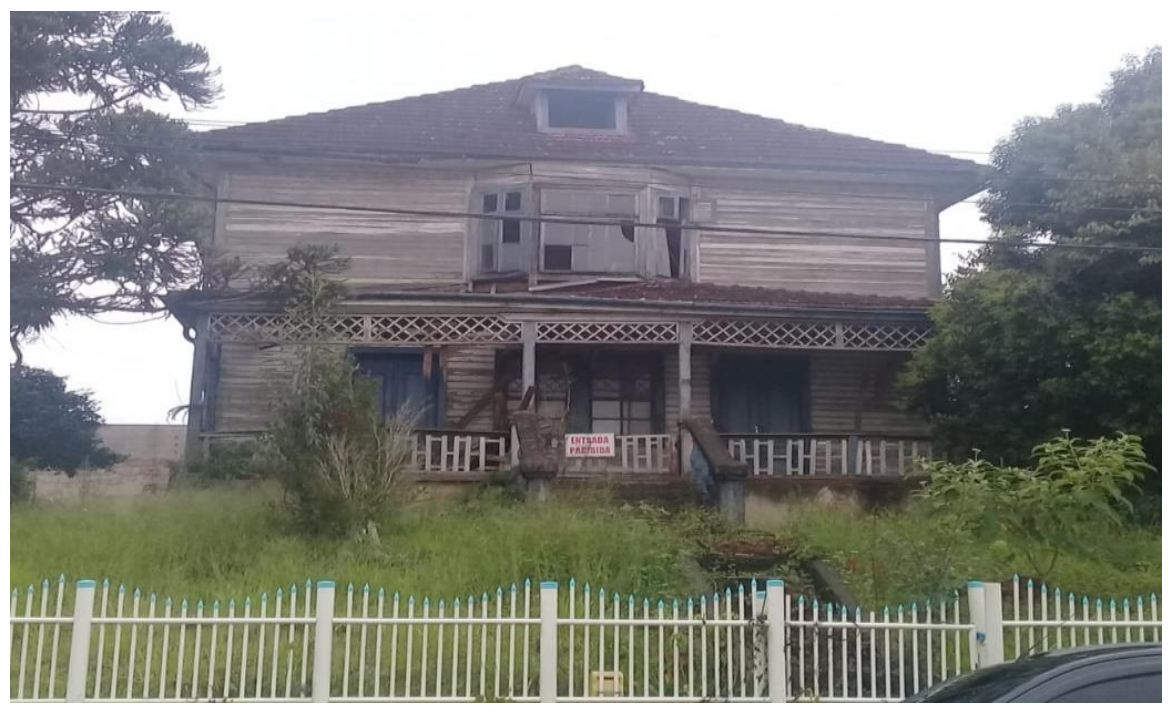

Fonte: Adimari (2019).

Devido a dinâmica oriunda do fim do século XIX, a cidade não era simplesmente um espaço físico, mas um produto da natureza humana, capaz de se

\footnotetext{
${ }^{20}$ A madeira foi extensivamente utilizada na construção de casas, igrejas, escolas e estabelecimentos comerciais. Pequenos palacetes ingleses, ditos "assobradados" e dotados de arremedos de torres ao gosto eclético, envidraçados (com baywindows) (IPHAN,2011).
} 
adaptar às mudanças ocorridas pelo desenvolvimento industrial e apta a contribuir para esse progresso. Assim, a intensificação e mecanização da exploração da madeira fizeram com que inúmeras serrarias fossem instaladas no sul do país, permitindo a padronização e difusão da arquitetura em madeira (ZANI, 2013).

Ainda em relação a arquitetura de madeira, Zani (2013), destaca que originalmente as edificações eram totalmente elaboradas em madeira, elevadas pouco mais de um metro acima do solo, com telhas também de madeira, assim como os fechamentos e acabamentos. Em telhados fortemente inclinados, existiam os sótãos, quase sempre habitáveis ou com a função de depósito. Era comum também o prolongamento da água dianteira formando um avarandado.

Gradativamente, esse modelo foi sendo modificado com o acréscimo de novos espaços, a utilização de peças padronizadas que definiam a dimensão da fachada. As ampliações aconteciam no sentido longitudinal e as varandas passaram a apresentar localização variada. Adveio a utilização de lambrequins ${ }^{21}$ (Figura 05), principalmente no telhado, que tinha a função de pingadeira, proteção do beiral, além de constituir elementos decorativos. E a cobertura foi sendo substituída por telhas escamadas ou francesas.

Figura 05 - Residência na região central de canoinhas, construída em 1920.

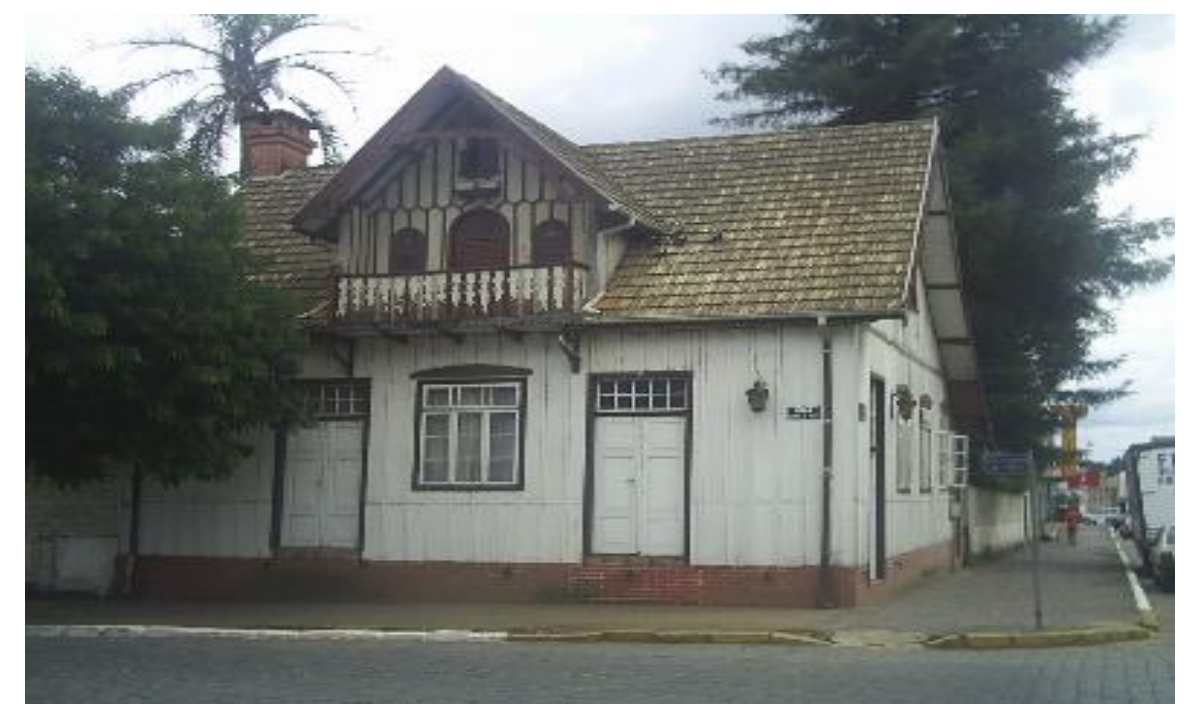

Fonte: Adimari (2019)

\footnotetext{
${ }^{21} \mathrm{Na}$ arquitetura, o lambrequim é um adorno recortado, que se coloca sob um friso, uma alheta, um beiral, ou outros elementos. No Brasil, o lambrequim foi muito utilizado no estado do Paraná, Santa Catarina e Rio Grande do Sul, principalmente pelos imigrantes italianos, ucranianos, alemães e poloneses, que encontraram maior facilidade em construir suas casas em madeira, pela grande quantidade de araucárias, cedros, imbuias e outras madeiras nobres presentes nessa região. Em Curitiba, o registro das primeiras obras data do fim do século XIX (IPHAN, 2011).
} 
Os aspectos técnicos e estéticos são característicos das diferentes culturas dos imigrantes que se instalaram na região, e proporcionaram a miscigenação étnica e arquitetônica. Contudo, as características dos imigrantes perderam a unidade estética e apareceram de forma fragmentada, em composição com outros detalhes arquitetônicos que se popularizaram e se uniformizaram no tempo e no espaço. Assim sendo, a arquitetura é marcada por telhados empinados, quase sempre com a presença do sótão e com uma multiplicidade de detalhes, como lambrequins, frontões, varandas, guarda corpo e beirais, que dificultavam uma única descrição (CLARO,1991).

Conforme Pinto (2005), a definição de técnica é a capacidade humana de intervir qualificadamente no mundo para a produção da sua existência, uma atividade consciente e planejada, inventiva, reflexiva e pensante. A intervenção é situada social e culturalmente, sendo o trabalho o exercício social da técnica. Em conformidade com Sigaut (2009), o trabalhador está inserido em comunidades de cultura própria, que interagem com outros grupos sociais, de culturas distintas.

As técnicas construtivas se desenvolveram sob a combinação das culturas europeia e indígena local. As formas utilizadas nas construções eram europeias, porém as técnicas construtivas em madeira, e o conhecimento das possibilidades do material, eram indígenas. Esse quadro modificou-se consideravelmente a partir do século XIX, com as políticas de incentivo à imigração. A diversidade cultural e ética inserida no país proporcionou a matização e evolução das técnicas construtivas e de exploração da madeira. Esse fato influenciou o surgimento de novas soluções e inovações arquitetônicas, pois os imigrantes trouxeram seus costumes, seu modo de viver, e seu modo de construir (HOFFMAN; PELEGRINI. 2009).

Por conseguinte, na região do Planalto Norte Catarinense, além da influência dos imigrantes Europeus, constata-se a herança deixada pelos caboclos. A experiência cabocla se deu no embate com a floresta virgem e foi de invenção, pois obtinham o que necessitavam sem fazer uso de muitos artifícios, e ainda sobrava tempo para festividades. Eles também contavam com o Pixirum, auxílio mútuo para a construção de casas e benfeitorias comunitárias (PIMENTA ET ALL, 2012).

Hoffman e Pelegrini (2009) afirmam que o conhecimento para a construção das edificações configura a tradição de "saber fazer". Esse conhecimento resulta de experiências de vida, de trocas culturais com outros imigrantes adquiridas muitas vezes nos mutirões de obras comunitárias, favorecendo o desenvolvimento de uma 
uniformização progressiva da técnica e do sistema construtivo, tornando-se característicos da região.

Sobre esse aspecto, Pimenta et all (2012) enfatiza que na realização do fazer artesanal está implícito, também, o termo "artífice", que demonstra uma aproximação mais direta com a "arte". Acrescenta que o mestre é aquele que domina um saber, no sentido de "maîtriser", definindo-se o artífice como "mestre numa arte, o que faz algo com arte, artesão, artista, especialista, oficial, criador, inventor, obreiro'. Os mestres artífices são, em grande parte, os construtores dos símbolos de representação da cultura local, nas diferentes áreas de migração que ocorreram a partir de meados do século XVIII.

A técnica tradicional utilizada no Planalto Norte Catarinense tem origem na tradição artesanal europeia, e foi trazida pelos imigrantes a partir de 1849 . O processo imigratório continuou nos séculos XIX e XX, assim como o intercâmbio de técnicas. A formação dos mestres artífices carpinteiros na região se deu através do aprendizado com um artificie específico na localidade, e na igreja, onde eram ensinadas as técnicas construtivas para os colonos e caboclos.

O aprendizado da técnica durava cerca de três anos, período no qual o aprendiz era recrutado para trabalhar com o mestre, sem receber contraprestação pecuniária, apenas a alimentação e a moradia caso estivesse distante da família. Inclusive, a família desses aprendizes deixava dinheiro para os mestres como uma garantia contra a desistência do aprendizado da técnica, sendo este dinheiro devolvido após o término da experiência. Depois disso, tornava-se um oficial, prosseguindo seu aprendizado ao menos por dez anos, com diferentes mestres, a fim de se converter em um mestre artífice. (PIMENTA et all, 2012).

O aprendiz, contudo, também era capacitado a fazer orçamentos, lidar com o cliente e, especialmente, a trabalhar seguindo um padrão de qualidade próprio, fato que distinguia o trabalho de um aprendiz do executado por um mestre. Também era comum a transmissão do conhecimento dentro do próprio núcleo familiar, já que se tratava de uma sociedade rural. Foi com o surgimento das cidades que os profissionais começaram a se dedicar exclusivamente à construção, mormente em decorrência da construção da estrada de ferro que ligava São Paulo ao Rio Grande do Sul, a qual mobilizou ingentes forças produtivas da região, difundindo assim o trabalho assalariado e promovendo o alargamento da divisão social do trabalho. ${ }^{22}$

22 Cunha; Espíndola (2015, p. 41) comentam que a divisão do trabalho é característica de todas as sociedades conhecidas. A divisão do trabalho dentro de unidades produtivas é peculiar da sociedade 
Com a decadência do trabalho artesanal e o surgimento das máquinas, os jovens perderam o interesse pelo trabalho artesanal, que foi ultrapassado pela urgência da sociedade. Esse fato exigiu que os mestres se engajassem na construção moderna, participando do trabalho das indústrias de esquadrias e móveis, que surgiram na região. Aquelas indústrias, em sua maioria, eram comandadas pelos imigrantes e reproduziam o sistema de trabalho importado da Europa, com três anos de relação entre mestres e aprendizes. Portanto, o surgimento dos acessos ferroviários e rodoviários promoveram o aumento da produção e do número de indústrias na região, exigindo mestres para a construção de novos galpões e manutenção dos existentes. Assim, muitos mestres foram trabalhar como empregados assalariados nas indústrias da região.

Os mestres que se mantiveram autônomos tiveram que se modernizar para aumentar a produtividade e acompanhar os preços do mercado. Suas antigas ferramentas de carpintaria foram substituídas por ferramentas elétricas, mais eficientes e seguras. Com isso, o artesão, que era autor do processo, obteve refinamento. $O$ resultado dessas maneiras peculiares de arte construtivas se mostra claramente na malha urbana do município de Canoinhas, sobretudo na forma da técnica e na forma estética das construções em madeira.

\section{Considerações Finais}

Inicialmente, a região do Planalto Norte Catarinense, na qual se insere o município de Canoinhas, era habitada por populações indígenas, e com a abertura do caminho das tropas ocorreu o prolongamento dos laços sociais da região, bem como a ampliação de contatos culturais. Destarte, o caboclo compunha a maior parte da população da região. No final do século XIX e início do século XX, elevouse a presença de imigrantes europeus. Esse novo grupo populacional aderiu ao

capitalista, pois serve para o aumento proporcional das forças produtivas do trabalho. O aumento da produção e da produtividade do trabalho, em consequência da divisão do trabalho, ocorre devido a três circunstâncias distintas: (i) maior destreza existente em cada trabalhador; (ii) poupança daquele tempo que, geralmente, seria costume perder ao passar de um tipo de trabalho para outro; (iii) invenção de um grande número de máquinas que facilitam e abreviam o trabalho, possibilitando a uma única pessoa fazer o trabalho que, de outra forma, teria de ser feito por muitas. Ainda, a divisão do trabalho é a consequência necessária de certa tendência existente na natureza humana à propensão, a intercambiar, a permutar ou a trocar uma coisa pela outra. A divisão do trabalho dentro das unidades produtivas pressupõe concentração dos meios de produção nas mãos de um capitalista e é imposta pelo planejamento, controle e, em consequência, aumenta a produtividade do trabalho e diminui o dispêndio improdutivo da força de trabalho. 
modo de vida da população cabocla e aos seus costumes, podendo-se destacar hábito de tomar chimarrão, produto proveniente da erva mate, um dos principais produtos da economia regional.

Em consequência do coronelismo e do advento da Lei de Terras (1850), houve a proibição de acesso dos caboclos aos ervais nativos, em prejuízo de sua subsistência. Além dessas peculiaridades do processo histórico, no início do século XX se estabeleceu naquela região a Lumber Company, cuja atuação resultou na expulsão dos caboclos das terras, exploração da madeira e venda de lotes para os imigrantes europeus. A empresa estrangeira também promoveu a devastação da mata nativa da região. Porém, constatou-se que a Lumber Company teve papel importante na formação econômica e social do município Canoinhas.

Após o genocídio praticado contra a população cabocla do Contestado, as décadas subsequentes foram marcadas pela consolidação de uma matriz produtiva extrativista e extremamente excludente. Embora a economia da erva-mate tenha proporcionado o crescimento econômico da região, a partir dos anos 1930, distintos fatores resultaram na decadência paulatina desse setor. Assim, a madeira, outro produto derivado da matriz produtiva, cuja extração e beneficiamento em larga escala se iniciaram com o processo de colonização, acabou por se consolidar na região, apresentando crescimento e representatividade no decorrer dos anos.

Em consequência da abundância de matérias primas existentes na formação física do território e da consolidação de uma matriz produtiva imposta pelas classes dominantes, a região do município de Canoinhas foi marcada por ciclos econômicos da erva mate e da madeira. Sendo assim, a formação do território foi influenciada pela luta de sua população contra as forças capitalistas (ferrovia, Lumber, imigrantes e coronéis). Esse conjunto de fatores sociais, naturais, culturais e econômicos foi decisivo para a formação da identidade do município de Canoinhas, e influenciaram peremptoriamente a construção do patrimônio arquitetônico, sobretudo de madeira, símbolo material e imóvel da identidade de um grupo populacional.

No entanto, percebe-se que a população da região pouco conhece e valoriza o seu patrimônio arquitetônico em madeira, o qual assume, de fato, a condição de símbolo de sua identidade. Além disso, constata-se um certo descaso do poder público para com este símbolo tangível de sua identidade territorial, haja vista que não foram identificadas quaisquer ações legais para preservação dos bens arquitetônicos da região, tampouco campanhas em prol da-conscientização e prevenção, que poderiam ser implementadas pelos órgãos públicos competentes. 


\section{REFERÊNCIAS}

ADIMARI, Cinthia Wambier. O patrimônio arquitetônico e suas possibilidades pedagógicas para fomentar o desenvolvimento regional em Canoinhas/SC. 2019. Dissertação (Dissertação de Mestrado em Desenvolvimento Regional). Canoinhas. Programa de Mestrado em Desenvolvimento Regional. Universidade do Contestado. BARTMANN, Scheila Karina Bockor. Memória social e desenvolvimento: Uma análise do processo histórico de produção de erva-mate no município de Canoinhas. 2009. Dissertação (Dissertação de Mestrado em Desenvolvimento Regional). Programa de PósGraduação em Desenvolvimento Regional. Universidade de Santa Cruz do Sul. BENKO, Georges; PECQUEUR, Bernard. Os Recursos de Territórios e os Territórios de Recursos. Geosul, Florianópolis, v. 16, n. 32, p. 32-50, 2001.

BOGO, Amilcar J. Arquitetura em madeira em Santa Catarina. Vitruvius, Brasilia, v. 208, n. 2, p.1-12, set. 2017. Acesso em: 10 de dezembro de 2018. Disponível em: http://www.vitruvius.com.br/revistas/read/arquitextos/18.208/6717. BRASIL. Lei no 601, de 18 de setembro de 1850.

CAMILO, Irene. Desenvolvimento do turismo baseado em elementos culturais. Turismo \& Sociedade, Curitiba, v. 1, n. 10, p.1-12, jan. 2017.

CHOLLEY, André. Observações sobre alguns pontos de vista geográficos. Boletim Geográfico, Rio de Janeiro, n. 179, p. 139-145, 1964.

CLARO, Anderson. Casas de Madeira em Santa Catarina. 1991. Dissertação (Dissertação de Mestrado em Arquitetura), São Paulo. USP.

CUNHA, Roberto César. Ocupação e desenvolvimento das duas formações sócio espaciais do Maranhão. Cadernau-cadernos do Núcleo de Análises Urbanas, Rio Grande, v. 8, n. 1, p.133-152, jan. 2015.

CUNHA, Roberto. César; ESPÍNDOLA, Carlos José. A geoeconomia da produção de soja no sul do Maranhão: características sociais e territoriais. Revista da ANPEGE, São Paulo, ANPEGE, n. 16, v.11, p. 37-65, jul./dez., 2015.

DALLABRIDA, Valdir Roque. Teorias do Desenvolvimento. Curitiba. Editora CRV, 2017. ESPÍNDOLA, Carlos José.; CUNHA, Roberto César. A dinâmica geoeconômica recente da cadeia produtiva de soja no Brasil e no Mundo. Geotextos, v. 11, n. 1, p. 217-238, Salvador, UFBA, 2015

FERREIRA, Thiza. Atividade madeireira no meio oeste catarinense e a Vila de Campina Redonda. Revista Santa Catarina em História, Florianópolis, v. 1, n. 2, p.59-65, jan. 2009. FRAGA, Nilson Cesar. Mudanças e permanências na rede viária do Contestado: Uma nova abordagem acerca da formação territorial no sul do Brasil. 2006. Tese (Tese de Doutorado em Meio Ambiente e Desenvolvimento), UFPR, Curitiba.

FUNARI, Pedro Paulo; PELEGRINI, Sandra de Cássia Araújo. Patrimônio histórico e cultural. Coleção Ciências Sociais Passo a Passo. Zahar Editor, 2006.

GLASS, Ruth. London: aspects of change. Londres, Centre for Urban Studies/MacGibbon e Kee, 1964.

GRAD, Guilherme Freitas. Ensaio sobre a madeira: metodologia, fontes de pesquisa, pensamentos expeditos. Florianópolis: Iphan, 2008. 14 p.

HOFFMANN, Alessandra Corsato; PELEGRINI, Sandra. A técnica em construir em madeira: um legado do patrimônio cultural para a cidade Maringá. In: CONGRESSO

INTERNACIONAL DE HISTÓRIA, 4., 2009, Maringá. UEM, 2009. p. 4089 - 4097.

HORTA, Maria de Lourdes Parreiras; GRUNBERG, Evelina; MONTEIRO, Adriane

Queiroz. Guia básico para educação patrimonial. 1999. Acesso em: 09 set. 2018.

Disponível em:

http://portal.iphan.gov.br/uploads/temp/quia educacao patrimonial.pdf.pdf.

IBGE. Geografia do Brasil: Rio Grande do Sul. Rio de Janeiro, v. IV, T. II, 1968. Acesso

em 10 de jan.2019. Disponível em

http://biblioteca.ibge.gov.br/visualização/livros/liv81435 v4 t2.pdf. 
IPHAN (Instituto de patrimônio Histórico e Artístico Nacional). Roteiros Nacionais de Imigração: Santa Catarina. Dossiê de Tombamento. Volume 2. O modelo de ocupação do território. Santa Catarina: Iphan, 2011.

JORNAL Correio do Norte. O ano novo e o progresso de Canoinhas. 31/12/1955.

LUCHIARI, Maria Tereza Duarte Paes. A reinvenção do patrimônio arquitetônico no consumo das cidades. GEOUSP-Espaço e Tempo, São Paulo v. 17, p. 95-105, 2005. MACHADO, Paulo Pinheiro. Lideranças do Contestado: a formação das chefias caboclas (1912-1916). Campinas, SP. Editora da Unicamp, 2004.

MACHADO, Paulo Pinheiro. Um estudo sobre as origens sociais e formação política das lideranças sertanejas do Contestado. 2001. Tese (Tese de Doutorado em História). Programa de Pós-graduação em História. Universidade Estadual de Campinas. Campinas. MARCHESAM, Jairo. A Paisagem Natural na Região do Contestado: da exuberância da mata nativa do passado à cobertura vegetal com espécies exóticas no presente. In: DALLABRIDA, Valdir Roque (Org.). Território, identidade territorial e desenvolvimento regional: reflexões sobre Indicação Geográfica e novas possibilidades de desenvolvimento com base em ativos com especificidade territorial. São Paulo: Liber Ars Ltda, 2013.

MELLO E SOUZA, Antônio Cândido. Os Parceiros do Rio Bonito: estudos sobre o caipira paulista e a transformação dos seus meios de vida. São Paulo: Duas Cidades, 2001.

MILANI, Maria Luiza. Identidade sócio-cultural do planalto norte catarinense: uma realidade (in) visível. Revista Científica Ciência em Curso, v. 2, n. 2, p. 125-131, Palhoça,2014. NIGRO, Cíntia. "Patrimônio cultural e território urbano". Boletim Paulista de Geografia, São Paulo, n.78, p.45-75, (2001).

OLIVEIRA, Tarcísio Dorn; DINIZ, Bruna Calabria; WILDNER Gabriel da Silva. Educação e arquitetura: reflexões relacionadas ao ato de preservar o patrimônio cultural edificado. IvCiecitec, Rio Grande do Sul, v. 11, n. 9, p.1-7, out. 2017.

PELEGRINI, Sandra de Cássia Araújo. O patrimônio cultural no discurso e na lei: trajetórias do debate sobre a preservação no Brasil. Patrimônio e Memória, Maringá, v. 2, n. 2, p. 5477, 2007.

PIMENTA, Margareth de Castro Afeche et al. Mestres Artífices de Santa Catarina. 2. ed. Brasilia: Iphan, 2012.

PINTO, Álvaro. O conceito de tecnologia. Rio de Janeiro: Contraponto, v. 2, 2005.

ROCHA, Thaíse Sá Freire. Refletindo sobre memória, identidade e patrimônio: as contribuições do programa de Educação Patrimonial do MAEA-UFJF. In: ANPUH, 18., 2012, Maringá. Encontro regional. Anpuh, 2012. v. 1, p. 1 - 12.

ROLNIK, Raquel. O que é cidade? 3. ed. São Paulo: Brasiliense, 2009. 87 p.

SANTOS, Milton. Espaço e método. São Paulo: Nobel, 1985.

SANTOS Milton. Sociedade e Espaço: a formação social como teoria e como método. In:

Boletim Paulista de Geografia, São Paulo, v. 54, p. 81-99, jun. 1977.

SIGAUT, François. Techniques, technologies, apprentissage et plaisir au

travail. Techniques\&Culture. n.52-53, p. 40-49, 2009.

SILVA, Elsa Peralta. Património e identidade. Os desafios do turismo

cultural. Antropológicas, Lisboa v.01, n. 4, p. 217-224, 2000.

TOMPOROSKI, Alexandre Assis. Do antes ao depois: a influência da Lumber Company para a deflagração do movimento sertanejo do Contestado e seu impacto na região fronteiriça entre Paraná e Santa Catarina. Revista Esboços, Florianópolis, v. 19, n. 28, p.68-87, dez. 2012.

TOMPOROSKI, Alexandre Assis. O patrimônio agrário como estratégia de desenvolvimento da comunidade autônoma de Castilla-La Mancha (Espanha) e sua aplicabilidade à microrregião de Canoinhas (Santa Catarina, Brasil). In: SEMINÁRIO INTERNACIONAL DE INTEGRAÇÃO E DESENVOLVIMENTO REGIONAL, 5., 2018, Toledo. Anais. Toledo: Unioeste, 2018. v. 1, p. 1 - 20.

TOMPOROSKI, Alexandre Assis. Os costumes no planalto catarinense: dos embates no movimento sertanejo do Contestado à luta contra as imposições do capital estrangeiro

(1912-1919). Revista Brasileira de História \& Ciências Sociais, v. 7, n. 14, p. 27-56, 2015. 
TOMPOROSKI, Alexandre Assis. Do Movimento Sertanejo do Contestado (1912-1916) à contemporaneidade - o domínio fundiário no Território do Contestado. 2016. Acesso em: 05 jan. 2019.

Disponível em: http://www.anpuh-sc.org.br/rev\%20front\%2028\%20vers\%20fin/f28-artdoss5alexandre-assis.pdf

TOMPOROSKI, Alexandre Assis. O polvo e seus tentáculos: A Southern Brazil Lumber and Colonization Company e as transformações impingidas ao planalto Contestado, 1910-1940. 2013. Tese (Tese de Doutorado em História) - Programa de Pós-graduação em História. UFSC. Florianópolis.

TOMPOROSKI, Alexandre Assis; MARCHESAN, Jairo. Planalto Norte Catarinense: algumas considerações sobre aspectos históricos, características físico-naturais e extrativismo.

Desenvolvimento Regional em debate, v. 6, n. 2, p. 51-63, 2016.

VALENTINI, Delmir José; RADIN, José Carlos. Camponeses no sertão catarinense: In: SIMPÓSIO NACIONAL DE HISTÓRIA, 26., 2011, São Paulo. Anais. São Paulo: Anpuh, 2011.

ZANI, Antônio Carlos. Arquitetura em Madeira. Londrina: Eduel, 2013. 397 p.

ZANIRATO, Silvia Helena; RIBEIRO, Wagner Costa. Patrimônio cultural: a percepção da natureza como um bem não renovável. Revista Brasileira de História, São Paulo, v. 26, n. 51, p. 251-262, 2006.

\section{NOTAS DE AUTOR}

\section{CONTRIBUIÇÃO DE AUTORIA}

Cinthia Wambier Adimari - Concepção. Coleta de dados, Análise de dados, Elaboração do manuscrito, revisão e aprovação da versão final do trabalho.

Alexandre Assis Tomporoski - Concepção. Coleta de dados, Análise de dados, Elaboração do manuscrito, revisão e aprovação da versão final do trabalho.

\section{FINANCIAMENTO}

Não se aplica.

\section{CONSENTIMENTO DE USO DE IMAGEM}

Não se aplica.

\section{APROVAÇÃO DE COMITÊ DE ÉTICA EM PESQUISA}

Não se aplica.

\section{CONFLITO DE INTERESSES}

Não se aplica.

\section{LICENÇA DE USO}

Este artigo está licenciado sob a Licença Creative Commons CC-BY. Com essa licença você pode compartilhar, adaptar, criar para qualquer fim, desde que atribua a autoria da obra.

\section{HISTÓRICO}

Recebido em: 21-04-2019

Aprovado em: 30-09-2019 